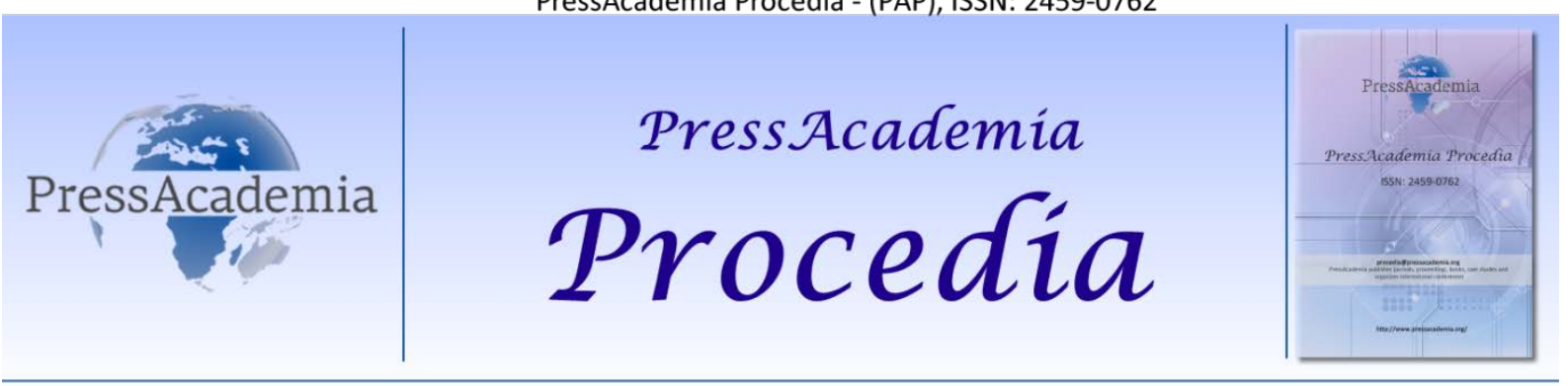

Global Business Research Congress (GBRC), May 26-27, 2016, Istanbul, Turkey.

\title{
VISUAL ELEMENTS' EFFECT ON MOBILE APPLICATION PREFERENCE
}

DOI: 10.17261/Pressacademia.2016118656

\section{Gokhan Aydin}

Istanbul Arel University. aydin.gokhan@gmail.com

\begin{abstract}
Mobile devices and related services are attracting the interest of both marketing academicians and professionals as well as entrepreneurs. Mobile applications (apps) that work on these devices are promoted as individual service products or as supplementary services. In this context, this study aims to reveal the effect of visual elements in mobile app choice using app icons, the primary visual elements affecting consumer choice. The icons provide the first impression and are considered as the most frequently seen visual elements of apps. The visual and cognitive elements; color, symmetry, complexity, concreteness, familiarity and meaningfulness dimensions are used as icon characteristics. By utilizing the PAD model developed by Mahrabian and Russell, the effect of icon characteristics on users' dispositions and on download intentions was tested. Moreover, the effect of visual icon attributes on perceived quality was tested using the data collected through an online survey study. The analysis was carried out using structural equation modelling. This study aims to enable mobile app developers in improving their designs by revealing the effect of various visual elements on consumers' mobile app download intentions and expected to pioneer further studies in Turkey.
\end{abstract}

Keywords : Mobile marketing, mobile applications, online consumer behavior, aesthetics in consumer behavior JEL Codes: M30, M31, L82

\section{TÜKETICILERIN MOBiL UYGULAMA TERCIHINDE GÖRSEL ÖĞELERIN ETKISi}

\section{ÖZET}

Günümüzde kullanımı hızla yaygınlaşmakta olan mobil cihazlar ve ilgili hizmetler hem pazarlama akademisyenlerinin ve profesyonellerinin hem de girişimcilerin ilgisini çekmektedir. Mobil cihazlar üzerinde çalışan mobil uygulamalar birer hizmet ürünü veya ürünleri zenginleştirici öğeler olarak pazara sunulmaktadır. Tüketicilerin uygulama tercihinde etkili olan faktörler içerisinde yer alan görsel öğeler arasında ikonlar öne çıkmaktadır. Bu çalışmada ikonların görsel ve bilişsel öğeleri renk, simetri, karmaşıklık, somutluk, anlamlı olma ve aşinalık alt boyutlarıla incelenmiştir. Mahrabian ve Russell tarafından geliştirilen PAD modelinden faydalanılarak ikonların niteliklerinin duygu durumlarına ve uygulama indirme niyetine etkisi sınanmıştır. Tüketici algıları Internet üzerinden yoklama yöntemi yardımıyla ölçülmüş ve her bir faktörün uygulama indirilme niyetine etkisi yapısal eşitlik modellemesinden faydalanılarak belirlenmiştir. Bu faktörlere ek olarak uygulamanın estetik öğelerinin ilk izlenimle oluşan algılanan kaliteye etkisi de sınanmıştır. Bu araştırmayla mobil uygulamaların başarısında rol oynayan görsel unsurların belirlenerek uygulama geliştiricilerin tasarımlarını iyileştirmelerini sağlayacak sonuçlar elde edilmesi ve Türkiye'deki ileri araştırmalara yol gösterilmesi hedeflenmiştir.

Anahtar Kelimeler: mobil uygulamalar, mobil pazarlama, çevrimiçi tüketici davranışı, estetik ve tüketici davranışı JEL Kodları: M30, M31, L82 


\section{Giriş}

Günümüzde tüketicilerin neredeyse günün her saati yanlarında taşıdıkları mobil cihazların sunduğu fırsatlar pazarlama alanında gerek araştırmacıların gerekse profesyonellerin yoğun ilgisini çekmektedir. Dünya genelinde kullanımda olan aktif cep telefonu hattı sayısı 1997'de 200 milyondan 2005'te 2,2 milyara ve 2014 yılında ise dünya nüfusunu geçerek 7 milyar adede yaklaşmıştır (International Telecommunication Union, 2014). ComScore (2014)'un araştırmasına göre A.B.D.'de kullanıcıların yaklaşık \%60'ı Internet erişiminde öncelikli olarak mobil cihazları tercih etmektedirler ve Movable Ink'in araştırmasına göre pazarlama e-postalarının \%65'i mobil cihazlar üzerinden açılmaktadır (Burdge, 2014). Dünya genelinde mobil cihazların popülerliğiyle birlikte mobil uygulama sayısı da hızla artmaktadır. Birçok yeni girişimci gerek ana ürün olarak gerekse destekleyici hizmet olarak mobil uygulamalara odaklanmaktadır. Bu kalabalık içerisinden sıyrılabilmek için ise farklılaşmak gerekliliği ortaya çıkmaktadır. Mobil uygulamalar özelinde düşünüldüğünde uygulamaların çoğunun ücretsiz olması sebebiyle tüketicilerin ürün tercihinde öncelikli olarak değerlendirdikleri fiyat boyutunda rekabet avantajı yaratmak oldukça zordur. Bir diğer önemli etken olan kalitenin de mobil uygulamalarda önceden değerlendirilmesi oldukça zordur. Bu nedenle ilk göze çarpan ve ilk izlenim oluşmasında önemli olan görsel öğeler, bununla ilişkili olarak tasarım ve estetik, mobil uygulama tercihinde diğer birçok ürün ve hizmete kıyasla daha da önem kazanmaktadır. Bu araştırma içerisinde tüketicilerin tercihlerine görselliğin etkisi uygulama ikonları özelinde incelenmiştir. Mobil uygulamaların indirilme davranışına etki eden görsel öğe olarak literatürde uygulamanın ikonu öne çıkmaktadır. İkon kullanıcıların uygulamayla ilgili en sık gördükleri öğedir. Mobil uygulamalar alanındaki literatür incelendiğinde ağırlıklı olarak metin tabanlı veya sayısal analizlere dayanan ve görsel özelliklerle ilgili olmayan çalışmalar göze çarpmaktadır. Uygulamaların indirilme sayıları, beğenilme sayıları, yapılan yorumların sayısı ve nitelikleri (olumlu/olumsuz), uygulamayı destekleyen cihaz ve işletim sürümü uygulama tercihinde etkin olan öğeler olarak öne çıkmaktadır (Ho ve Tu, 2012; Hou ve Ho, 2013; Pol, 2015). Literatürde yer bulmuş olan birçok farklı nesnel faktörün incelendiği çalışmaların varlığına rağmen görsel öğelerin incelendiği çalışmalar kısıtlıdır (Hou ve Ho, 2013; Pol, 2015). Türkiye'de ise bu alanda gerçekleştirilmiş benzer bir çalışma bulunmamaktadır. Buradan hareketle ortaya çıkan araştırma boşluğunu doldurmak için bu çalışma hayata geçirilmiştir. Genel kabul görmüş estetik teorilere dayanarak gerçekleştirilmiş olan bu çalışmanın uygulama geliştiricilere yardımcı olması, sınırlı akademik literatürü zenginleştirmesi ve ülkemizde alanına öncülük etmesi beklenmektedir.

\subsection{Mobil Uygulamalar}

Mobil uygulama belirli bir amaca yönelik olarak mobil cihazlar üzerinde çalışmak üzere tasarlanmış yazılımlara verilen isimdir. Mobil uygulamalar akılı cep telefonlarının gelişmiş ve gelişmekte olan ülkelerde hızlı yayılımının ardından 2008 yılında ortaya çıkmış ve çok hızlı bir şekilde bireylerin günlük hayatına girerek iletişim, paylaşım, sosyalleşme, bilgiye erişim ve eğlenme şekillerinde önemli değişikliklere neden olmuşlardır. Bu gelişmeler paralelinde mobil uygulamaların ticari değeri de hızlı bir şekilde yükselmiştir. Örneğin Finlandiyalı oyun geliştiricisi Rovio firması birçok maddi olarak başarısız oyundan sonra Angry Birds'ü piyasaya sürmüş, bu oyun ile çalışanlarına ve hissedarlarına milyonlarca dolar kazandırmıştır (Kendall, 2011). Mobil uygulama pazarı hakkında TMR'ın yayınladığı rapora göre 2013 yılında uygulama pazarı 16.97 milyar USD büyüklüğe ulaşmıştır. Pazar büyüklüğünün 2020 yılına kadar yıllık ortalama \%16'nın üzerinde bir büyüme göstererek üç katına çıkması beklenmektedir. Uygulamaların indirilme sayısının ise 2014'de 102 milyardan 2017'de 269 milyara ulaşacağı tahmin edilmektedir (Chaudhari, 2015). Günümüzde farklı pazaryerleri üzerinde kullanıcıların beğenisine sunulmuş 3.1 milyondan fazla mobil uygulama vardır (Technavio, 2015). Eğlence amaçlı ve oyun kategorilerinde yer alan uygulamalar 2013 yılında mobil uygulama pazarının \%40'lık bir bölümünü alarak, en büyük kategori olarak öne çıkmışlardır (Chaudhari, 2015). Türkiye'de mobil uygulama pazarı incelendiğinde, dünya genelindeki hızlı büyüme paralelinde ülkemizde de mobil uygulamaların indirilme sayılarının ve bu uygulamalara harcanan paranın ve kaynağın hızla arttığı görülmektedir. Türkiye uygulama pazarında yıllık \%60 büyüme ile en hızlı büyüyen ülkeler arasındadır. Türkiye'deki genel bilişim harcamalarındaki yıllık \%9 büyümeye kıyasla mobil uygulamalarda yaşanan bu hızlı büyümenin önemli fırsatlar ortaya koyduğu açıktır (App Annie \& MEF, 2014).

Mobil uygulamaların da içerikleri, ihtiyaçları karşılama oranları ve kalitelerinin kullanıcılar tarafından önceden tahmin edilmesi güçtür. Kullanıcıların uygulamaları kullanmadan önce tam olarak değerlendirmeleri de zordur. Çoğu hizmet ürünü için söz konusu olan bu durum (Lovelock ve Wirtz, 2011, s. 61) milyonlarca uygulamanın yer 
aldığı küresel uygulama pazar yerlerinde daha da önem kazanmaktadır. Kullanıcıların ilgilendikleri alandaki tüm alternatif uygulamaları indirip denemeleri operasyonel sebeplerden mümkün olamamaktadır. Bu durumda kullanıcı uygulama tercihinde özellikleri birbirine yakın olan uygulamalar arasında seçim yapmakta zorlanmaktadır. Bu alanda ilk izlenime etkisi olan görsel öğelerin incelendiği araştırmalar alanında bir boşluk göze çarpmaktadır.

\section{LITERATÜR TARAMASI}

Ürün tercihinde görsel öğelerin ve estetiğin ilgi uyandırma ve olumlu tutum oluşturma konusunda önemli bir unsur olduğu tüketici davranışları alanında gerçekleştirilmiş olan birçok çalışmada ortaya konulmuştur (Baisya ve Das, 2008, s. 88). Dünya genelinde hızla yükselişte olan mobil uygulamalar alanında yapılmış çalışmalar artış göstermesine rağmen ülkemizde bu alanında gerçekleştirilen bilimsel çalışmalar kısıtıdır. Bilimsel çalışma veritabanı Scopus incelendiğinde mobil uygulama ("mobile app"; "mobile apps" veya "mobile application") başlığındaki çalışmaların 2010 yılında 174 adetten 2014 yılında 587 adede ulaştığı görülmektedir. 2008 yııında sonra gerçekleştirilen çalışmalar içerisinde ABD'den 604 çalışma, Almanya'dan 201, G.Kore'den 191 çalışma yer alırken ülkemizden sadece 22 çalışma yer aldığı görülmektedir. Ülkemizde gerçekleştirilen bu çalışmaların ise sadece 3 tanesi veritabanında yer alan uluslararası hakemli dergilerde yayınlanmış makaledir ve çoğunluğu bildirilerden oluşmaktadır.

Mobil uygulamalarla ilgili tüketici davranışları alanındaki araştırmalarda uygulamaların tercih edilmesi ve indirilmesine etki eden faktörleri inceleyen çalışmalarda yorum sayısı, uygulama özellikleri, fiyat, tüketici tutumu gibi etkenlere odaklanıldığını görmekteyiz (Garg ve Telang, 2013; Ghose ve Han, 2014; Hou ve Ho, 2013). Mobil uygulama tercihinde etkili olan faktörler olarak çevrimiçi benzer çalışmalara paralel olarak fiyatın etkisi, marka ismi ve kulaktan kulağa pazarlama gibi unsurlar ve kullanıcıların verdikleri puanlar ve yorumlarının satın alma niyetine etki ettiği görülmüştür (Carare, 2012; Degeratu, Rangaswamy ve Wu, 2000; Liang, Li, Yang ve Wang, 2015). Ayrıca mobil uygulama alanındaki sınırı sayıda çalışmada uygulamanın arayüz tasarımı gibi unsurların da tercih üzerinde etkisi olduğu görülmüştür (Ghose ve Han, 2014). Ancak uygulamalar hakkında ilk izlenimin oluşmasında etkili olan ikonların etkisi bu çalışmalarda ele alınmamıştır. Bu çalışmalar içerisinde gerek metin temelli analizler gerekse sayısal unsurların mobil uygulama tercihi ve indirilme sayıları üzerine etkileri ortaya konulmuştur. Mobil oyunların indirilmesine yorumların (Hou ve Ho, 2013) diğer uygulamalar arasındaki sırasının tercihe etkileri (Garg ve Telang, 2013), çeşitli uygulama özelliklerinin uygulama indirilme sayılarına etkisi gibi konular (Ghose ve Han, 2014) mobil uygulama tüketici tercihi çalışma alanlarında öne çıkan alanlardır. Bu çalışmalarda mobil uygulama tercihine etki eden yukarıda sunulmuş olan faktörlerden de görülebileceği üzere görsel özellikler üzerine birkaç istisna dışında (Ghose ve Han, 2014; Pol, 2015) geniş çaplı çalışmalar yapılmamıştır. Mobil pazaryerlerinde tanıtımlarda öne çıkan, ilk izlenim yaratılmasında etkin olan (Wooldridge ve Schneider, 2010) uygulama ikonlarının uygulama tercihine olası etki şekilleri test edilmemiştir. Benzer bir alanda, web sayfaları üzerinde yapılan çalışmalarda kullanıııların çok kısa bir süre içerisinde (saniyenin 20'de biri) web sayfasıyla ilgili ilk izlenimlerini oluşturdukları ve bu izlenimin uzun vadede tutarlı şekilde devam ettiği görülmüştür. Bu bulgu ilk izlenimin görsel öğeler yardımıyla hızlı bir şekilde oluştuğu ve ilerleyen zamanda aynı kaldığına işaret etmektedir (Lindgaard, Fernandes, Dudek ve Brown, 2006). Bu ve benzeri bulgular web sayfası tasarımlarında da ikonların önemli birer tasarım öğesi olarak görülmelerine sebep olmaktadır (Cyr, 2008).

Araştırma konusuna en yakın çalışma Pol (2015) tarafından tüketiciler üzerinde gerçekleştirilen bir yoklama çalışmasıdır. Bu çalışma içerisinde farkı ikon tasarım tarzlarına göre ayrıştıılan uygulamalar arasında tercihlerini belirten kullanıcıların genelinde belirli tasarım tarzlarının daha sık tercih edildiği görülmüştür. Uygulamanın eğlence amaçı ve bilgilendirici amaçı olması durumlarında farklı ikon tasarım tarzların beğenildiği bulgular arasında yer almaktadır.

Mobil uygulamalar özelinde düşünüldüğünde tüketicilerin genel olarak ürün tercihinde öncelikli olarak değerlendirdikleri fiyat boyutunda rekabet avantajı yaratmanın oldukça zor olduğu görülmektedir. Bir diğer önemli etken olan kalitenin de mobil uygulamalar için tüketiciler tarafından önceden değerlendirilmesi oldukça zordur. Uygulamaların fonksiyonelliğin de teknoloji seviyesine paralel olarak benzerlik gösterdiği dikkate alındığında farklılaşma noktasında duygusal, hedonik ve sembolik faydaya odaklanma gözlenmektedir. Bu nedenle tasarım ve estetik konusu mobil uygulama tercihinde diğer birçok ürün ve hizmete kıyasla daha da önem kazanmaktadır (Hirschman ve Holbrook, 1982). 


\subsection{Tasarım ve Estetik}

Tasarım bir objenin unsurlarının ne şekilde oluşturulduğuyla ilgilidir ve görülebilen fiziksel unsurlarla yani görsellikle yakından ilintilidir. Bir objenin görselliği ise estetik özellikleriyle değerlendirilmektedir. Estetik unsurlar olarak form/şekil, renk, doku, simetri gibi öğeler öne çıkmaktadır (Veryzer, 1995). Estetik algı içerisinde gerek rengin etkisi gerekse biçimin simetrisi, yalınlığı ve kendi içindeki uyumu (harmonisi) yüzyıllardır beğeniyle ilişkilendirilmektedir. Simetri erken dönem Yunan felsefesinden itibaren güzellik ve beğenilmeyle ilişkilendirilmiştir (Tunali, 2011, s. 209). Simetrinin insanlar tarafından beğenilmesi bir anlamda gerek doğada gerek insan bedeninde kusurları olmayana işaret etmesinden kaynaklanır (Tunali, 2011, s. 216).

Görsellikte bir diğer önemli unsur ise renktir. Günümüzde tüketici davranışları alanında yapılan çalışmalarda hem çocuklar hem yetişkinler arasında rengin duygusal algılar üzerine etkileri gözlenmiş ve satın alma eğilimini etkileyebildiği görülmüştür (Boyatzis ve Varghese, 1994; Hemphill, 1996; Joshi ve diğerleri, 2011).

Ürün tasarımında ve mekan tasarımında kullanılan öğelerin, tasarımın estetik özelliklerinin tüketici algıları ve davranışları üzerine etkileri birçok araştırmaya konu olmuştur. Ürün tasarımının tüketicilerin algısı üzerine etkisi ve ürünün başarısındaki rolü bilinmesine rağmen (Norman, 2004) dijital alanda yapılan çalışmalar daha kısıtlıdır. Yine de bu alana olan ilginin artması, günümüzde dijitalleşmeyle birlikte uygulama ve sistem ara-yüz Internet üzerindeki hizmetlerin ve sayfaların tasarımı gibi farklı alanlarda yapılan çalışmalar önemli bulgulara ulaşılmasını sağlamıştır (Ahmed, Al Mahmud ve Bergaust, 2009; Thüring ve Mahlke, 2007). Bu paralelde ikonlarla ilgili estetik öğelerin incelendiği çalışmalar ve kaynaklar literatürde kısıtlı da olsa yer almaktadır (Hou ve Ho, 2013; Pol, 2015; Wooldridge ve Schneider, 2010).

Görselliğin ve tasarımın tüketici davranışlarına etkisiyle ilgili pazarlama literatürü incelendiğinde hizmet pazarlaması ve perakendecilikte tüketici davranışlarına konu olan Mehrabian ve Russell tarafından kurgulanan Uyarı Cevabı Modeli (SOR) ve PAD modellerinin bu alanda yer bulduğunu görmekteyiz (Mehrabian ve Russell, 1974).

\subsection{Uyarı Cevabı Modeli ve PAD}

Uyarı Cevabı Modeli kişilerin çevrelerine nasıl tepki verdikleriyle ilgili temel bir modeldir. Bu modelin önemli unsurlarından birisi duyguların müşterilerin hizmet ortamlarına tepkilerinin temel tetikleyicisi olarak görülmesidir (Mehrabian ve Russell, 1974). Çevre psikolojisi alanında Mehrabian ve Russell (1974) tarafından ortaya konulmuş olan bu modele göre, çevrede birçok uyarıcı bulunmaktadır. Bu uyarıcılar kişilerin durumlarını etkilemekte ve onların davranışlarını yönlendirmektedir. Bu yaklaşımda çevresel uyaranlar bireylerde memnuniyet, uyarılma ve baskınlık boyutlarında duygulara sebep olmaktadır. Bireyin bu uyaranlara nihai tepkisi ise yaklaşma veya kaçınma olarak iki temel davranışla sonuçlanmaktadır (Donovan ve Rossiter, 1982; Russell ve Snodgrass, 1987). Bu temel modelden hareketle geliştirilen çalışmalarda duyguların tüketicilerin satın alma davranışları üzerinde etkisi olduğu gözlenmiştir (Donovan ve Rossiter, 1982; Sherman, Mathur ve Smith, 1997). Mehrabian ve Russell tarafından geliştirilen PAD modelinin tüketicilerin mağaza ortamında duygularını yakalamada başarılı olmakta ve diğer tüketici davranışı alanlarında da geçerliliği test edilmektedir. Tüketicilerin reklamlara olan yaklaşımlarının belirlenmesinde (Holbrook ve Batra, 1987), internet sayfaları ve elektronik perakendecilik gibi alanlarda bu modelden başarılı şekilde faydalanılmıştır (Menon ve Kahn, 2002).

\subsubsection{Uyarılma}

Model içerisinde yer alan uyarılma boyutu duyusal uyarım, miktarını, heyecanlanma miktarını ifade etmektedir (Eroglu, Machleit ve Davis, 2003). Komplike, beklenmedik, hızlı uyaranlar kişileri heyecanlandırmakta ve yaklaşma cevabı doğurmaktadır (Sherman ve diğerleri, 1997). Ancak bunun tersi durumlar da literatürde gözlenmektedir (Menon ve Kahn, 2002). Araştırmacılar uyaran miktarının çok artmasının olumsuz davranışlara sebep olduğunu gözlemlemişlerdir (Massara, Liu ve Melara, 2010).

\subsubsection{Hoşlanma}

Bu model kapsamında hoşlanmanın tanımı 'bireyin mutlu, iyi, memnun, tatmin olmuş hissetme derecesi' olarak tanımlanmaktadır (Eroglu ve diğerleri, 2003). Gerçekleştirilmiş olan çalışmalarda web sayfalarının renklerinin, 
kullanılan grafiklerin ve görsel öğelerin kullanıcıların hoşlanma miktarına etkidiği görülmüştür (Koo ve Ju, 2010) Elektronik perakendeciler üzerinde yapılan çalışmada web sayfası estetiğinin ve atmosferinin müşterilerin satın almadan aldıkları hazzı etkilediği ortaya konulmuştur (Cai ve Xu, 2011; Eroglu ve diğerleri, 2003). Benzer şekilde bilgisayar programları ara yüzlerinin kullanıııların hoşlanma miktarını etkilediği çalışmalarla kanıtlanmış bir durumdur (Lavie ve Tractinsky, 2004).

\section{3. İkonun Görsel Unsurları}

Estetiğin dijital ortamlarda tanımlanması için yapılan çalışmalarda birçok alt boyutun ortaya konulduğunu görmekteyiz. Bu çalışmalarda ortak olan görsel öğeler olarak simetri/denge, basitlik/karmaşıklık ve renklilik öne çıkmaktadır (Choi ve Lee, 2012; Moshagen ve Thielsch, 2010; Shu ve Lin, 2014; Tuch, Bargas-Avila ve Opwis, 2010). Web-sayfalarında estetik algııının oluşması ve ilk izlenim üzerine bu unsurların etki ettiği ilgili çalışmalarda ortaya konulmuştur (Reinecke ve diğerleri, 2013).

Bir görüntünün ve mekanın ne derece karmaşık veya yalın olduğunun duyular üzerine etkisi birçok çalışmaya konu olmuştur. Tüketici davranışları alanında karmaşıkık konusuyla ilgili literatür incelendiğinde çevresel estetik alanında ve hizmet pazarlamasında sıklıkla yer alan Mehrabian Russell modeli ve bunun üzerine geliştirilmiş olan çalışmalar göze çarpmaktadır. Mekandaki karmaşıkı̆̆ın kişilerdeki uyarılma miktarını artırdığı gözlenmiştir (Gilboa ve Rafaeli, 2003; Nasar, 2000). Bu durum bireylerin karmaşık bir çevre/ durum karşısında birçok bilgiyi işlemek ve yorumlamak için odaklanması ve çaba göstermesi ihtiyacı ile ilintilidir. Karmaşıklık kişilerin ilgisinin uyandırılması için tercih edilebilen bir değişken olarak tasarımda kullanılabilmektedir (Kaplan ve Kaplan, 1983). Bu alanda yapılan çalışmalarda görüldüğü üzere tasarımdaki düzen ise bireylerin uyarılma miktarını azaltmaktadır (Gilboa ve Rafaeli, 2003; Lavie ve Tractinsky, 2004). Düzenin artması çevrenin kolayca ve az çabayla algılanması sonucunu getirmekte ve bireylerin rahatlamasına sebep olarak uyarılma miktarını azaltmaktadır (Kaplan ve Kaplan, 1983; Nasar, 2000). Görsel karmaşıklı̆ın ve simetrinin kullanıcıların tercihleri üzerindeki etkileri de çeşitli araştırmalara konu olmuştur (Creusen, Veryzer ve Schoormans, 2010). Örneğin simetrinin kullanıcıların web-sayfalarını değerlendirmeleri üzerinde etkisinin olduğu gözlenmiştir (Bauerly ve Liu, 2006). Ayrıca (Shu ve Lin, 2014) ikonların denge ve karmaşıklığının oyun uygulama tercihlerine etkisi olduğunu ortaya koymuşlardır. Bu bulgulardan hareketle düzenin ikonlar üzerindeki göstergesi olarak simetriyi çalışma içerisine dahil ederek, karmaşıklığın ve düzenin etkisiyle ilgili aşağıdaki hipotezleri oluşturmaktayız:

$\mathrm{H}_{1}$ : Karmaşıklık arttıkça bireylerin uyarılma miktarı artacaktır.

$\mathrm{H}_{2}$ : Simetri arttıkça bireylerin uyarılma miktarı azalacaktır.

$\mathrm{H}_{3}$ : Karmaşıklık arttıkça bireylerin hoşlanma miktarı artacaktır.

$\mathrm{H}_{4}$ : Simetri artııķa bireylerin hoşlanma miktarı artacaktır.

Bir diğer görsel öğe olan renk ve renkliliğin bireyler üzerindeki etkisinin rengin üç temel unsurundan ileri geldiği ifade edilmektedir, bunlar ton, yoğunluk/doygunluk ve değerdir. Ton genel olarak rengin pigmentini yani kırmızı gibi asıl rengi ifade ederken değer rengin ne derece açık ve koyu olduğunun ifadesidir. Yoğunluk/doygunluk ise rengin parlaklığının/matlığının göstergesidir (Spalter, 1999, s. 170). Renklerin çağrışımları kültürler arasında farkıılaşmasına ve yaş ile cinsiyetten etkilenmesine rağmen aynı kültür ve yakın yaş gruplarında tutarlıık göstermektedir (Chebat ve Morrin, 2007; Singh, 2006). Canlı ve parlak renklerin tüketicileri uyardığı bilinen bir durumdur (Marberry ve Zagon, 1995, s. 18). Kişilerin renklere verdiği tutarlı tepkiler, mağaza ve otel lobisinden web sayfası tasarımına kadar farklı alanlarda tasarımcıları yönlendirmektedir (Countryman ve Jang, 2006). Renklerin bireyler tarafından algılanması konusunda hem bilişsel hem de bilinçaltında algılandığına dair teoriler vardır, her ne şekilde algılanırsa algılansın renklerin kişilerin duyguları ve değerlendirmeleri üzerinde etkisi olduğu kabul edilmektedir (Papachristos, Tselios ve Avouris, 2005; Skorinko, Kemmer, Hebl ve Lane, 2006).

$\mathrm{H}_{5}$ : Renklilik arttıkça bireylerin uyarılma miktarı artacaktır.

$\mathrm{H}_{6}$ : Renklilik arttıkça bireylerin hoşlanma miktarı artacaktır. 


\section{4. İkonun Bilişsel Unsurları}

İkonların görsel unsurlarına ek olarak bilişsel unsurları da bireylerin değerlendirmesinde etkin olmaktadır. Bilişsel unsurlar görsel unsurlara göre daha sübjektif ve kişiye bağlıdır. Görsel unsurlarla ilgili algoritmalar yardımıyla yapılan çalışmalar olmasına rağmen (Bauerly ve Liu, 2006; ör. Wu, Chen, Li ve Hu, 2011) bilişsel unsurlar insan faktörünün çalışmaya dahil edilmesini bir yerde zorunlu kılmaktadır. Literatürde kabul görmüş olan bilişsel unsurlar olarak aşinalık/tanıma, somutluk, karmaşıklık ve konuyla ilgili olma ve anlamlılık boyutları öne çıkmaktadır (McDougall, Curry ve de Bruijn, 1999). Aşinalık ikonun bireyler tarafından ne sıklıkla karşılaşıldığını ve tanındığını göstermektedir. Somutluk ise ikonun gerçek nesneleri, kişileri vb. ifade ettiğinin veya etmediğinin (soyutluğunun) bir göstergesidir. İkonun komplike/karmaşık olarak algılanması literatürde hem bilişsel hem de görsel bir öğe olarak yer bulmaktadır. Burada karmaşıklık ikon içerisindeki detayı, çok nesne, çizgi bulunmasını ifade etmektedir. Bu kavramın tersi olarak yalınlık az sayıda objeye sahip olması kabul edilmektedir. Anlamlılık ise ikonu değerlendiren kişinin bu ikonu ne kadar anlamlı bulduğu, semantik mesafe de konuyla ilişkili bulup bulmadığının bir göstergesidir (McDougall ve diğerleri, 1999; Ng ve Chan, 2008). Bu çalışma kapsamında semantik mesafe ve anlamlılık boyutu ölçümünde kullanılan ilgili ölçeklerin Türkçe ifadeleri ve algılanmalarında pilot çalışmada katılımcılar arasında yaşanan kavram karmaşası/problemlerden dolayı tek bir faktör olarak ele alınmıştır.

$\mathrm{H}_{7}$ : Somutluk arttıkça bireylerin uyarılma miktarı artacaktır.

$\mathrm{H}_{8}$ : Anlamlılık arttıkça bireylerin uyarılma miktarı azalacaktır.

$\mathrm{H}_{9}$ : Aşinalık arttıkça bireylerin uyarılma miktarı azalacaktır.

$\mathrm{H}_{10}$ : Somutluk arttıkça bireylerin hoşlanma miktarı artacaktır.

$\mathrm{H}_{11}$ : Aşinalık arttıkça bireylerin hoşlanma miktarı artacaktır.

$\mathrm{H}_{12}$ : Anlamlılık arttıkça bireylerin hoşlanma miktarı artacaktır.

\subsection{Algılanan Kalite}

Algılanan kalite tüketicinin zihninde bir ürünün, kullanım amacına göre performansını, alternatiflerine göre üstünlüğünü ve güvenirliliğini göstermektedir (Zeithmal, 1988). Tüketicilerin karşısına uygulama arama esnasında çıkan ve ilk izlenim oluşmasında etkili olan görsel öğelerin (Choi ve Lee, 2012) uygulamanın içeriği ve kalitesinin bir göstergesi olarak tutum geliştirilmesi ve kullanıcının ilgisini çekmesini test eden sınırlı sayıda çalışma vardır (Forsythe, Sheehy ve Sawey, 2003; Liang ve diğerleri, 2015). Ürünlerin karmaşıklığı, renkliliği, yerleşimleri gibi özelliklerin algılanan kaliteye ve tercihe etki ettiği dijital mecralarda gözlenmiştir (Pol, 2015; Taba, Keivanloo, Zou, Ng ve Ng, 2014; Wu ve diğerleri, 2011). Buradan hareketle aşağıdaki hipotezleri oluşturuyoruz:

$\mathrm{H}_{13}$ : Karmaşıklık arttıkça algılanan kalite artacaktır.

$\mathrm{H}_{14}$ : Simetri arttıkça algılanan kalite artacaktır.

$\mathrm{H}_{15}$ : Renklilik arttıkça algılanan kalite artacaktır artacaktır.

$\mathrm{H}_{16}$ : Somutluk arttıkça algılanan kalite artacaktır artacaktır.

$\mathrm{H}_{17}$ : Aşinalık arttıkça algılanan kalite artacaktır artacaktır.

$\mathrm{H}_{18}$ : Anlamlılık arttıkça algılanan kalite artacaktır artacaktır.

\subsection{Uygulama Indirme Niyeti}

Uygulama pazar yerleri içerisinde yer alan uygulamaların büyük çoğunluğu ücretsizdir. Bu çalışma kapsamında yer verilen uygulamalar da ücretsiz biçimde indirilebilmekte olduklarından satın alma niyeti yerine uygulama indirme niyeti terimi kullanılmıştır. Literatürde uygulamalı çalışmalarda olumlu duygu durumlarının satın alma davranışına pozitif yönde etki ettiğini ortaya koyulmuştur (Donovan, Rossiter, Marcoolyn ve Nesdale, 1994; Menon ve Kahn, 2002). Uyarılma ile ilgili elde edilen çelişkili sonuçlara kıyasla hoşa gitme ile ilgili sonuçlar 
tutarlı bir şekilde satın alma davranışına olumlu etkiyi ortaya koymaktadır. Uygulama indirme niyetinin bu çalışma içerisinde Mahrabian ve Russell modelindeki uyarılma ve beğenme değişkenlerinden ve algılanan kaliteden olumlu yönde etkilenmesi beklenmektedir. Bu kapsamda aşağıdaki hipotezler oluşturulmuştur:

$\mathrm{H}_{19}$ : Uyarılma arttıkça uygulama indirme niyeti artacaktır.

$\mathrm{H}_{20}$ : Hoşa gitme seviyesi arttıkça indirme niyeti artacaktır.

$\mathrm{H}_{21}$ : Algılanan kalite arttıkça uygulama indirme niyeti artacaktır.

\section{VERI VE YÖNTEM}

Bu çalışma kapsamında ortaya konulmuş olan hipotezlerin test edilebilmesi için Google Play mobil uygulama pazaryerinden faydalanılmışır. Google Play sayfasına anonim bir bilgisayar tarayıcısından kullanıc bilgileri girilmeden erişilmiştir. Fiyat boyutunun etkisini ortadan kaldırmak için sadece ücretsiz uygulamalar çalışmaya dahil edilmiştir. Mobil uygulama kategorisi olarak oyunlar seçilmiştir ve alt kategorilerden her iki cinsiyete ve farklı yaş gruplarına hitap edebilen arcade oyunları ve bulmaca oyunları arasından seçim yapııımışıı. Çalışmada 6 farklı ikon kullanılmıştı. Seçim aşamasında ise pazaryeri tarafından sunulan uygulama listesinde 13. uygulamadan başlayarak her onbeşinci uygulama seçilmiş ve toplam on ikondan oluşan bir liste yapılmıştır. Daha sonra bu listeden görsel ve bilişsel unsurlarda farklılaşabilecek birbirine benzemeyen, her bir oyun kategorisinden üçer ikon seçilmiştir ve Ek-1 içerisinde sunulmaktadır. Çalışmaya katılan katılımcılar kendilerine sunulan üç farklı uygulama ikonunu ayrı ayrı değerlendirmiştir. i̇konlarla ilgili bir karşılaştırma yaptırılmamıştır.

Veri setindeki ilişki sayısının yüksek olması ve görece olarak gözlem sayısının kısıtlı olmasından hareketle en küçük kareler yapısal eşitlik modellemesi yardımıyla değişkenler arasındaki ilişkiler ortaya konulup yorumlanmıştır.

Yapılan çalışma mobil cihaz kullanımı yaygın olan Y-kuşağı üyeleri hedeflenerek gerçekleştirilmiştir ve çalışmaya sadece akıllı telefon cihazı kullanıcıları dahil edilmiştir. 20 akademisyen ve öğrenci üzerinde gerçekleştirilen pilot çalışmayı takiben soru formu ve ifadeler düzenlenerek araştırmaya geçilmiştir. Pilot çalışma sonrasında anlamlıık ve semantik yakınlık boyutlarıyla ilgili karışıkıklar olduğu ve ifadelerin birbirlerine yakınlık gösterdiği fark edilmiştir. Bu sebepten bu iki unsur tek bir faktör altında çalışmaya dahil edilmiştir. Çalışmaya toplam 112 kişi katılmış olup elde edilen formlardan $101^{\prime} i$ kullanılabilir bulunmuştur. Örneklem incelendiğinde katılımcıların \%48'i kadın \%52'si erkek olduğu görülmektedir. Yaş dağııımında 18-21 yaş arasına ait olanlar örneklemin \%32'sini $22-27$ yaş arası \%41'ini 28 yaş üzeri ise \%27'sini oluşturmaktadır. Katılımcıların \%65'i 5 yıldan uzun süredir akıllı telefon kullandıklarını beyan etmişlerdir. 


\section{Şekil 1: Kurgulanan Model}

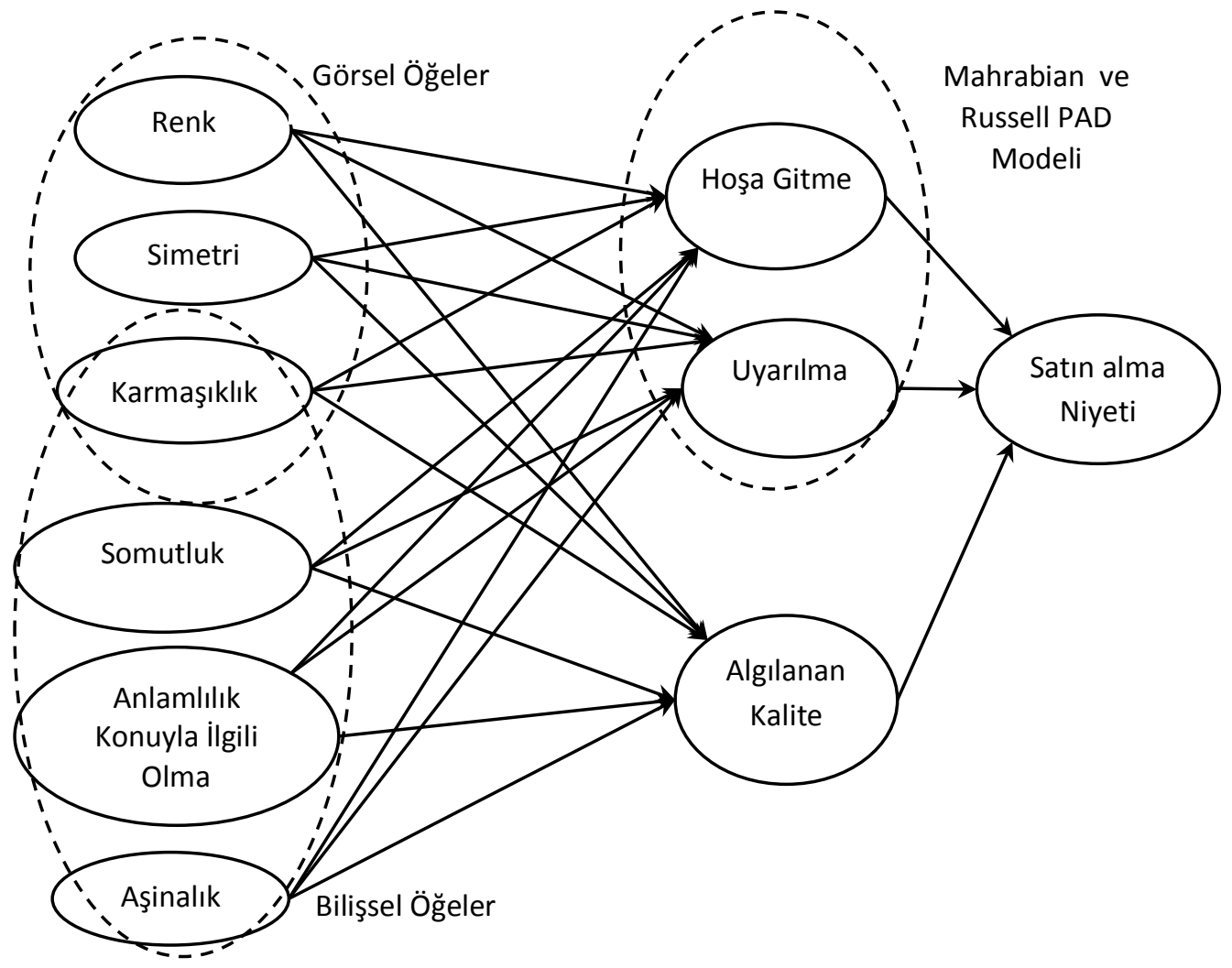

Çalışma içerisinde kullanılan değişkenler ve ilgili ölçekler Tablo 1 içerisinde sunulmaktadır. ilgili değiş̧kenlerin ölçülmesinde 7 noktalı Likert ölçek ve 7 noktalı semantik fark ölçeği kullanılmıştır.

Tablo 1: Ölçekler ve Sorular

\begin{tabular}{l|l}
\hline \multirow{2}{*}{ Uyarılma (Koo ve Ju, 2010) } & íkonu gördükten sonra şunları hissettim: \\
\cline { 2 - 2 } & 1. Aktif \\
\cline { 2 - 2 } & 2. Enerjik \\
\cline { 2 - 2 } & 3. Coşkulu \\
\hline \multirow{2}{*}{ Hoşa Gitme (Koo ve Ju, 2010) } & İkonu gördükten sonra şöyle hissettim: \\
\cline { 2 - 2 } & 1. Memnun \\
\cline { 2 - 2 } & 2. Mutlu \\
\cline { 2 - 2 } & 3. Neşeli \\
\hline Görsel ve Bilişsel Öğeler - 7 noktalı semantik ölçekte- (Ng ve Chan, 2008) \\
\hline Aşinalık & Çok tanıdık ----- Çok yabancı \\
\hline Somutluk & Kesinlikle soyut ------ Kesinlikle somut \\
\hline Basitlik & Çok karmaşık ----- Çok basit \\
\hline Anlamlılık & Konuyla çok ilgisiz ------ Çok ilgili \\
\hline Renklilik & Hiç Renkli Değil ------- Çok renkli \\
\hline Simetriklik & Hiç simetrik değil ------ Tam simetrik \\
\hline
\end{tabular}




\section{BULGULAR VE TARTIŞMA}

Kurgulanmış olan model içerisinde kullanılan ölçeklerin geçerlilik ve güvenilirliklerinin değerlendirilmesi için yapılmış olan analizlerin sonuçları Ek-2 içerisinde sunulmaktadır. Uyuşum geçerliliği test sonuçları tavsiye edilen seviyeler içerisinde kalmaktadır. Cronbach'ın alfası (CA) 0,80’den büyük; (Carmines ve Zeller, 1979; Nunnally, 1978); ortalama çıkarılan varyans (AVE) 0,50'den büyük; kompozit güvenilirlik (CR) ise 0,70'den büyüktür (Fornell ve Larcker, 1981).

Ayırdedici (diskriminant) geçerlik Fornell ve Larcker (1981) tarafından önerilen değişkenler arası korelasyonun ortalama çıkarılan varyansın kareköküyle karşılaştırılması yaklaşımıyla kontrol edilmiştir. Buna ek olarak örtük değişkenler arasındaki korelasyonlarının 0,90 sınırının altında kaldığı görülmektedir (Hair vd., 2013). Yine örtük değişkenler arası korelasyonların tamamı çıkarılan varyans değerlerinden düşüktür. Çapraz yüklemeler de incelendikten sonra elde edilen bulgulardan her bir göstergenin kendi örtük değişkeni üzerinde diğer değişkenlere kıyasla daha fazla etkiye sahip olduğunu göstermektedir.

En küçük kareler yapısal eşitlik modellemelerinde uyum iyiliğini ölçebilecek kabul görmüş tek bir ölçüt yoktur. Uyum iyiliği literatürde belirleme katsayısı $\left(R^{2}\right)$ ve kestirim uygunluğu $\left(Q^{2}\right)$ kriterleri kullanılarak saptanmaktadır (Hair, Hult, Ringle ve Sarstedt, 2013). Uygulama indirme niyeti $R^{2}$ değeri 0,494 olarak hesaplanmıştır ve modelin bu değişkeni orta derecede açıklama becerisine sahip olduğunu göstermektedir (Hair, Hult, ve diğerleri, 2013). Modelin tahmin becerisi ise Stone-Geisser'in $Q^{2}$ değeri yardımıyla irdelenmiştir (Geisser, 1974; Stone, 1974). $Q^{2}$ değeri göz bağlama (blindfolding) yöntemi yardımıyla, yani örtük değişkenle ilgili göstergelerin veri noktaları toplam veri-setinden çıkarılarak model tarafından sonradan tahmin edilmesi yaklaşımıyla hesaplanmıştır. Bu şekilde Orijinal veri değerleriyle modelin tahmin ettiği değerler arasındaki fark hesaplanarak modelin tahmin becerisi ve gücü ortaya konulmaktadır (Henseler, Ringle ve Sinkovics, 2009). Uygulama indirme niyeti için $Q^{2}$ değeri 0,456 olarak hesap edilmiştir ve 0,350 üzerindeki bu değer yüksek kestirim uygunluğuna (predictive relevance) işaret etmektedir (Hair, Hult, ve diğerleri, 2013; Henseler ve diğerleri, 2009). Elde edilen bu değerlerden hareketle kurgulanan modelin mobil uygulama indirme niyetini orta-yüksek derecede açıklama becerisine sahip olduğu görülmektedir.

Çalışma kapsamında gerçekleştirilmiş olan yapısal eşitlik modellemesi analiziyle elde edilen sonuçlar Tablo 2 içerisinde sunulmuştur. 
Tablo 2: Doğrudan Etkiler ve Hipotez testleri

\begin{tabular}{lllllll}
\hline Hipotez & Yol & Katsayı & Std. Hata & t- stat. & Hipot. doğrulandı mı? & Sig. \\
\hline $\mathrm{H}_{1}$ & BAS -> UYA & 0.0426 & 0.0606 & 0.703 & Hayır & - \\
$\mathrm{H}_{2}$ & SiM-> UYA & 0.2302 & 0.0585 & 3.9363 & Evet & $<0.001$ \\
$\mathrm{H}_{3}$ & BAS -> HOŞ & 0.0493 & 0.0693 & 0.7117 & Hayır & - \\
$\mathrm{H}_{4}$ & SiM-> HOŞ & 0.2336 & 0.0571 & 4.0889 & Evet & $<0.001$ \\
$\mathrm{H}_{5}$ & RNK-> UYA & 0.1237 & 0.0578 & 2.1407 & Evet & $<0.05$ \\
$\mathrm{H}_{6}$ & RNK-> HOŞ & 0.0134 & 0.0655 & 0.2049 & Hayır & - \\
$\mathrm{H}_{7}$ & SOM -> UYA & 0.0319 & 0.0632 & 0.5057 & Hayır & - \\
$\mathrm{H}_{8}$ & ANL -> UYA & 0.1943 & 0.0631 & 3.0777 & Evet & $<0.01$ \\
$\mathrm{H}_{9}$ & AŞN -> UYA & 0.0904 & 0.0596 & 1.5152 & Hayır & - \\
$\mathrm{H}_{10}$ & SOM -> HOŞ & 0.0281 & 0.0672 & 0.4189 & Hayır & - \\
$\mathrm{H}_{11}$ & AŞN -> HOŞ & 0.0678 & 0.0626 & 1.0828 & Hayır & - \\
$\mathrm{H}_{12}$ & ANL -> HOŞ & 0.1446 & 0.0716 & 2.0194 & Evet & $<0.05$ \\
$\mathrm{H}_{13}$ & BAS-> KAL & -0.0951 & 0.0671 & 1.4166 & Hayır & - \\
$\mathrm{H}_{15}$ & RNK-> KAL & 0.0922 & 0.0578 & 1.5955 & Hayır & - \\
$\mathrm{H}_{14}$ & SiM-> KAL & 0.2473 & 0.0618 & 4.0011 & Evet & $<0.001$ \\
$\mathrm{H}_{16}$ & SOM -> KAL & 0.0109 & 0.0608 & 0.1792 & Hayır & - \\
$\mathrm{H}_{17}$ & AŞN -> KAL & 0.101 & 0.0601 & 1.6805 & Hayır & - \\
$\mathrm{H}_{18}$ & ANL -> KAL & 0.2111 & 0.0687 & 3.0747 & Evet & $<0.01$ \\
$\mathrm{H}_{19}$ & UYA-> NiY & 0.0179 & 0.0647 & 0.2771 & Hayır & - \\
$\mathrm{H}_{20}$ & HOS -> NiY & 0.1366 & 0.0674 & 2.0264 & Evet & $<0.05$ \\
$\mathrm{H}_{21}$ & KAL -> NiY & 0.619 & 0.052 & 11.9045 & Evet & $<0.001$ \\
\hline
\end{tabular}

Elde edilen sonuçlar incelendiğinde mobil uygulama ikonunun görsel öğelerinden simetriklik boyutunun, bilişsel öğelerinden ise konuyla ilgili bulunmasının hem uyarılma hem de hoşa gitme üzerinde etkisi olduğu görülmektedir. Simetriklik'in yükselmesi hem uyarılma miktarını hem de hoşa gitme seviyesini artırmaktadır. Ayrıca simetriklik ve konuyla ilgili olma algılanan kalite üzerine de olumlu yönde etkimektedir. İkonun görsel öğelerinden olan renklilik özelliğinin uyarılma miktarını artırdığı da bulgular arasında yer almaktadır. Canlı ve parlak renklerin tüketicileri uyardığı ve heyecanlandırdığı farklı çalışmalarda da gözlemlenmiş bir durumdur (Marberry ve Zagon, 1995, s. 18).

Uygulama indirme niyetine doğrudan etkiyen değişkenler incelendiğinde hoşa gitme ve algılanan kalite iki önemli unsur olarak ortaya çıkmaktadır. Algılanan kalite uygulamayı indirme niyeti üzerinde güçlü bir etkiye sahiptir. Buna ek olarak Mahrabian ve Russell modeli dahilinde test edilen duygusal unsurlar olan uyarılma ve hoşa gitme faktörleri arasından sadece hoşa gitmenin uygulama indirme niyeti üzerinde etkiye sahip olduğu görülmektedir. İkonun sebep olduğu uyarılmanın uygulama indirme niyeti üzerine olumlu veya olumsuz yönlü etkisine bu çalışma içerisinde rastlanmamıştır. Daha önce de değinildiği üzere uyarılmanın satın alma niyeti üzerinde hem olumlu hem de olumsuz yönde etkileri literatürde gözlenmiştir ve bu konuda farklı görüşler vardır. Uyarılmanın heyecan ve tedirginlik olarak iki farklı boyutta incelenmesi bu tutarsızlığın önüne geçebilecek bir yaklaşım olarak literatürde göze çarpmaktadır (Koo ve Ju, 2010) ve ileriki araştırmalarda bu durum test edilebilir.

Sonuçların daha iyi yorumlanabilmesi için doğrudan olmayan etkiler göz önüne alınarak değişkenlerin toplam etkileri hesaplanarak Tablo 3 içerisinde sunulmuştur. 
Tablo 3: Toplam Etkiler

\begin{tabular}{|c|c|c|c|c|}
\hline iliş̧ki & Toplam Etki & Std.hata & t-statistics & Sig. \\
\hline UYA -> NiY & 0.0179 & 0.0647 & 0.2771 & - \\
\hline BST -> UYA & 0.0426 & 0.0606 & 0.703 & - \\
\hline BST -> KAL & -0.0951 & 0.0671 & 1.4166 & - \\
\hline BST $->$ NIY & -0.0514 & 0.0468 & 1.0968 & - \\
\hline BST -> HOŞ & 0.0493 & 0.0693 & 0.7117 & - \\
\hline KAL -> NiY & 0.619 & 0.052 & 11.9045 & $<0.001$ \\
\hline ANL $>>$ UYA & 0.1943 & 0.0631 & 3.0777 & $<0.01$ \\
\hline ANL $>$ KAL & 0.2111 & 0.0687 & 3.0747 & $<0.01$ \\
\hline ANL $->$ NiY & 0.1539 & 0.048 & 3.2079 & $<0.01$ \\
\hline ANL -> HOŞ & 0.1446 & 0.0716 & 2.0194 & $<0.05$ \\
\hline HOŞ -> NIY & 0.1366 & 0.0674 & 2.0264 & $<0.05$ \\
\hline RNK -> UYA & 0.1237 & 0.0578 & 2.1407 & $<0.05$ \\
\hline RNK $->$ KAL & 0.0922 & 0.0578 & 1.5955 & - \\
\hline RNK -> NIY & 0.0611 & 0.0421 & 1.4518 & - \\
\hline RNK -> HOŞ & 0.0134 & 0.0655 & 0.2049 & - \\
\hline SiM -> UYA & 0.2302 & 0.0585 & 3.9363 & $<0.001$ \\
\hline SiM $->$ KAL & 0.2473 & 0.0618 & 4.0011 & $<0.001$ \\
\hline SiM -> NiY & 0.1891 & 0.044 & 4.2974 & $<0.001$ \\
\hline SiM -> HOŞ & 0.2336 & 0.0571 & 4.0889 & $<0.001$ \\
\hline SOM -> UYA & 0.0319 & 0.0632 & 0.5057 & - \\
\hline SOM -> KAL & 0.0109 & 0.0608 & 0.1792 & - \\
\hline SOM -> NIY & 0.0112 & 0.0431 & 0.2587 & - \\
\hline SOM -> HOŞ & 0.0281 & 0.0672 & 0.4189 & - \\
\hline AŞN -> UYA & 0.0904 & 0.0596 & 1.5152 & - \\
\hline AŞN -> KAL & 0.101 & 0.0601 & 1.6805 & - \\
\hline AŞN -> NiY & 0.0734 & 0.0438 & 1.6759 & - \\
\hline AŞN -> HOŞ & 0.0678 & 0.0626 & 1.0828 & - \\
\hline
\end{tabular}

UYA: Uyarılma, BST: Basitlik, KAL: Kalite, ANL: Anlamlılık, NiY: Niyet, HOŞ: Hoşa Gitme, RNK: Renklilik, SiM: Simetrik, SOM: Somutluk, AŞN: Aşinalık

Toplam etkiler hesaplandığında doğrudan etki tablosunda sınanamamış olan ikonun görsel ve bilişsel unsurlarının uygulama indirme niyeti üzerindeki etkileri de ortaya konulmuştur. Tablo 3 içerisindeki toplam etkilerin incelenmesi sonucunda ikonun görsel bileşenlerinden olan karmaşıklık/basitliğin kalite algısı, kişilerin duyguları (uyarılma ve hoşlanma) ve indirme niyetleri üzerinde anlamlı bir etkisine rastlanmamıştır. Araştırmada elde edilen analiz sonuçlarına göre ikonlarla ilgili tüketicilerin değerlendirdiği bilişsel öğeler arasında incelenen ikonun tanıdık gelmesi (aşinalık), somut olarak algılanması unsurları da algılanan kalite, duygular ve indirme niyeti üzerinde istatistiki olarak anlamlı herhangi bir etkiye sahip değildir. Bilişsel unsurlar arasından ikonun konuyla ilgili ve anlamlı bulunması uygulama indirme niyetine olumlu yönde etkimektedir. 


\section{SONUÇ}

$\mathrm{Bu}$ araştırmada elde edilen çıkarımların, hem uluslararası alanda teorik araştırmalar için destekleyici nitelikte olması hem de tüm işletmeler için mobil uygulama alanında kullanıcı tercihlerini iyi anlayarak daha fazla tercih edilecek uygulamalar geliştirilmesine olanak sağlaması beklenmektedir. Mobil uygulamalar günümüzde gerek satış odaklı, gerek tanıtım odaklı, gerekse reklamlara aracılık eden bir mecra olarak kullanılmaktadırlar ve perakendeden spora birçok alanda mobil uygulamalar kullanıcıların beğenisine sunulmaktadır. Elde edilen bulgular özellikle mobil uygulama alanındaki kısıtlı tüketici davranışları literatürün geliştirilmesine katkıda bulunacak, hem de mobil uygulama ikonu geliştirme ve tasarımı konusunda yol gösterici olacaktır.

İncelenmiş olan görsel öğeler içerisinde uygulamayı indirme niyeti üzerine sadece simetriklik değişkeninin etki ettiği görülmüştür. İkonların simetriklik özelliğinin hem uygulamanın algılanan kalitesine etki ettiği hem de katılımcıların uyarılma miktarını artırdığı ve hoşuna gittiği görülmüştür. Katılımcıların simetrikliğin yüksek olduğu ikonları daha çok indirme niyetleri vardır. İkonun karmaşık/basit bulunmasının diğer değişkenler üzerinde etkisinin olmamasının bir sebebi ikonun görece küçük olmasından dolayı karmaşıklığın önemli bir etken olarak ortaya çıktığı web sayfaları, uygulama ara-yüzleri gibi ortamlardan daha küçük olması ve duygu durumunu değiştiremeyecek büyüklükte kalması verilebilir. Benzer şekilde uygulamanın katılımcılara tanıdık/yabancı gelmesi uyarılma ve beğeni üzerinde bir etkiye sahip değildir. Yabancı bulunan bir ikon, kullanıcıların duygu durumlarını veya uygulama indirme niyetlerini etkileyecek kadar önemli bulunmamıştır. Bir web sayfası veya uygulama içerisinde yabancılık çekilmesi, yabancı öğelerin bulunması durumunda kişilerde ortaya çıkabilecek olan tedirginlik hali uygulama ikonları incelendiğinde ortaya çıkmamıştır. Bilişsel unsurlar arasından uygulama indirme niyetine anlamlı bir etkisi olan yegane unsur ikonun konuyla ilgili, anlamlı bulunmasıdır.

Yapılan çalışmada elde edilen bir diğer sonuç da algılanan kalitenin uygulama indirme niyetine olumlu yöndeki etkisidir. Bu etki literatürde beklendiği şekilde ortaya çıkmıştır ve ikon vasıtasıyla oluşturulan kalite algısı katılımcılarda uygulamayı indirme isteğini güçlü biçimde artırmıştır. Uygulamanın kalite algısının pekiştirilmesinde ikonun simetrik olarak kurgulanması ve kullanıcıya anlamlı gelen, konuyla ilgili öğelerden oluşturulması etkili olmaktadır. Simetrikliğin algılanan kalite üzerine etkisi ikonun anlamlı/konuyla ilgili bulunmasının etkisinden daha yüksektir. Uygulama geliştiricilerin ikon tasarımında hem algılanan kaliteye hem de indirme niyetine etki eden bu iki unsurun üzerinde durmalarında fayda vardır.

Geçekleştirilmiş olan çalışmanın bazı kısıtları vardır. ilık olarak örnekleme yöntemi ve örneklem sayısının kısıtlı olmasını sayabiliriz. Ikinci olarak ise kullanılmış olan uygulama ikonlarının Google Play mağazası üzerindeki hazır uygulamalardan seçilmiş olmasıdır. Kurgu değil gerçek ikonlarla çalışmak ilerideki araştırmalarda uygulamayla ilgili nesnel bilgilerin ve ilgili faktörlerin indirilme niyetlerine ve gerçek indirilme sayılarını inceleme imkanı vermesine rağmen katılımcıların cevaplarında yanlılığa (bias) sebep olabilir. Kullanıcılara sunulmuş olan uygulama ikonlarını daha önce görmüş ve deneyimlemiş olan kişilerin ikon ile ilgili görüşleri daha önceki tecrübelerinden etkilenmiş olabilir. Son olarak çalışmanın katılımcılara uygulanması aşamasında katılımcıların konsantrasyonunun ne derecede ikon üzerine olduğu ve ikonu ne derece inceledikleri bilinmemektedir. İlerideki araştırmalar için deneysel çalışmalar ile her bir faktörün kurgulanmış ikonlar kullanılarak davranışlara veya indirme niyetine etkisinin test edilmesi faydalı olacaktır. Bu şekilde bu çalışmada elde edilen bulguların test edilmesi ve ilgili teorik altyapının mobil uygulamalarda geçerliliği sınanabilecektir.

\section{KAYNAKLAR}

Ahmed, S. U., Al Mahmud, A. ve Bergaust, K. (2009). Aesthetics in Human-Computer Interaction: Views and Reviews. Lecture Notes in Computer Science içinde (C. 5610 LNCS, ss. 559-568). doi:10.1007/978-3-642-02574-7_63

App Annie \& MEF. (2014). Emerging Markets and Growth in the Global App Economy.

Baisya, R. K. ve Das, G. G. (2008). Aesthetics In Marketing. Thousand Oaks: Sage Publications, Inc.

Bauerly, M. ve Liu, Y. (2006). Computational modeling and experimental investigation of effects of compositional elements on interface and design aesthetics. Int. J. Hum.-Comput. Stud., 64(8), 670-682.

Boyatzis, C. J. ve Varghese, R. (1994). Children's emotional associations with colors. The Journal of genetic psychology. 


\section{doi:10.1080/00221325.1994.9914760}

Burdge, B. (2014). New Research Shows Mobile Dominates Desktops. Movablelnk. http://blog.movableink.com/new-research-showsmobile-dominates-desktops-with-65-of-total-email-opens-in-q4-2013/ adresinden erişildi.

Cai, S. ve Xu, Y. (2011). Designing Not Just for Pleasure: Effects of Web Site Aesthetics on Consumer Shopping Value. International Journal of Electronic Commerce, 15(4), 159-188. doi:10.2753/JEC1086-4415150405

Carare, O. (2012). The impact of bestseller rank on demand: Evidence from the app market. International Economic Review, 53(3), 717742. doi:10.1111/j.1468-2354.2012.00698.x

Carmines, E. G. ve Zeller, R. A. (1979). Reliability and Validity Assessment. Sage University Papers Series. Beverly Hills, California: Sage Publications.

Chaudhari, A. (2015). Mobile Applications Market to Soar. Research, Transparency Market. 17 Eylül 2015 tarihinde http://www.transparencymarketresearch.com/pressrelease/mobile-applications-market.htm adresinden erişildi.

Chebat, J.-C. ve Morrin, M. (2007). Colors and cultures: Exploring the effects of mall décor on consumer perceptions. Journal of Business Research, 60(3), 189-196. doi:10.1016/j.jbusres.2006.11.003

Choi, J. H. ve Lee, H. J. (2012). Facets of simplicity for the smartphone interface: A structural model. International Journal of Human Computer Studies, 70(2), 129-142. doi:10.1016/j.ijhcs.2011.09.002

ComScore. (2014). The US Mobile App Report.

Countryman, C. C. ve Jang, S. (2006). The effects of atmospheric elements on customer impression: the case of hotel lobbies. International Journal of Contemporary Hospitality Management, 18(7), 534-545. doi:10.1108/09596110610702968

Creusen, M. E. H., Veryzer, R. W. ve Schoormans, J. P. L. (2010). Product value importance and consumer preference for visual complexity and symmetry. European Journal of Marketing, 44(9/10), 1437-1452. doi:10.1108/03090561011062916

Cyr, D. (2008). Modeling Web Site Design Across Cultures: Relationships to Trust, Satisfaction, and E-Loyalty. Journal of Management Information Systems, 24(4), 47-72. doi:10.2753/MIS0742-1222240402

Degeratu, A. M., Rangaswamy, A. ve Wu, J. (2000). Consumer choice behavior in online and traditional supermarkets: The effects of brand name, price, and other search attributes. International Journal of Research in Marketing, 17(1), 55-78. doi:10.1016/S0167-8116(00)00005

Donovan, R. J. ve Rossiter, J. R. (1982). Store Atmosphere: An Environmental Psychology Approach. Journal of Retailing, $58(1)$, 34. doi:Article

Donovan, R. J., Rossiter, J. R., Marcoolyn, G. ve Nesdale, A. (1994). Store atmosphere and purchasing behavior. Journal of Retailing, (70), 283-94.

Eroglu, S. a., Machleit, K. a. ve Davis, L. M. (2003). Empirical Testing of a Model of Online Store Atmospherics and Shopper Responses. Psychology \& Marketing, 20(2), 99-121. doi:10.1002/mar.

Fornell, C. ve Larcker, D. F. (1981). Evaluating Structural Equation Models with Unobservable Variables and Measurement Error. Journal of Marketing Research (JMR), 18(1), 39-50.

Forsythe, A., Sheehy, N. ve Sawey, M. (2003). Measuring icon complexity: an automated analysis. Behavior research methods, instruments, \& computers : a journal of the Psychonomic Society, Inc, 35(2), 334-342. doi:10.3758/BF03202562

Garg, R. ve Telang, R. (2013). Inferring App Demand From Publicly Available Data. MIS Quarterly, 37(4), 1253-1264.

Geisser, S. (1974). A predictive approach to the random effect model. Biometrika, 61, 101-107.

Ghose, A. ve Han, S. P. (2014). Estimating demand for mobile applications in the new economy. Management Science, 60(6), 1470.

Gilboa, S. ve Rafaeli, A. (2003). Store environment, emotions and approach behaviour: applying environmental aesthetics to retailing. The International Review of Retail, Distribution and Consumer Research, 13(2), 195-211. doi:10.1080/0959396032000069568

Hair, J. F., Hult, G. T. M., Ringle, C. M. ve Sarstedt, M. (2013). A Primer on Partial Least Squares Structural Equation Modeling (PLS-SEM) (1st bs.). Thousand Oaks: Sage Publications, Inc.

Hair, J. F., Tomas, G., Hult, M., Ringle, C. M. ve Sarstedt, M. (2013). A Primer on Partial Least Squares Structural Equation Modeling (PLSSEM) (1st bs.). Thousand Oaks: Sage Publications, Inc.

Hemphill, M. (1996). A note on adults' color-emotion associations. The Journal of genetic psychology, 157(3), 275-280. doi:10.1080/00221325.1996.9914865

Henseler, J., Ringle, C. M. ve Sinkovics, R. . R. (2009). The use of partial least squares path modeling in international marketing. Advances in international marketing, 20, 277-320.

Hirschman, E. C. ve Holbrook, M. B. (1982). Hedonic Consumption: Emerging Concepts, Methods and Propositions. Journal of Marketing, 


\section{6(3), 92. doi:10.2307/1251707}

Ho, S. C. ve Tu, Y. C. (2012). The investigation of online reviews of mobile games. Lecture Notes in Business Information Processing, 108 LNBIP(116), 130-139. doi:10.1007/978-3-642-29873-8-13

Holbrook, M. B. ve Batra, R. (1987). Assessing the Role of Emotions as Mediators of Consumer Responses to Advertising. Journal of Consumer Research, 14(3), 404. doi:10.1086/209123

Hou, K.-C. ve Ho, C.-H. (2013). A Preliminary Study on Aesthetic of Apps Icon Design. IASDR 2013 5th International Congress of International Association of Societies of Design Research, 1-12.

International Telecommunication Union. (2014). ICT Facts and Figures 2014. http://www.itu.int/en/ITU-

D/Statistics/Pages/stat/default.aspx adresinden erişildi.

Joshi, D., Datta, R., Fedorovskaya, E., Luong, Q., Wang, J., Li, J. ve Luo, J. (2011). Aesthetics and Emotions in Images. IEEE Signal Processing Magazine, 28(5), 94-115. doi:10.1109/MSP.2011.941851

Kaplan, S. ve Kaplan, R. (1983). Cognition and Environment: Functioning in an Uncertain World. Belmont, CA: Praeger Publishers.

Kendall, P. (2011). Angry Birds: the story behind iPhone's gaming phenomenon. The Telegraph. 17 Eylül 2015 tarihinde http://www.telegraph.co.uk/technology/video-games/8303173/Angry-Birds-the-story-behind-iPhones-gaming-phenomenon.html adresinden erişildi.

Koo, D.-M. ve Ju, S.-H. (2010). The interactional effects of atmospherics and perceptual curiosity on emotions and online shopping intention. Computers in Human Behavior, 26(3), 377-388. doi:10.1016/j.chb.2009.11.009

Lavie, T. ve Tractinsky, N. (2004). Assessing dimensions of perceived visual aesthetics of web sites. International Journal of Human Computer Studies, 60(3), 269-298. doi:10.1016/j.jjhcs.2003.09.002

Liang, T.-P., Li, X., Yang, C.-T. ve Wang, M. (2015). What in Consumer Reviews Affects the Sales of Mobile Apps: A Multifacet Sentiment Analysis Approach. International Journal of Electronic Commerce, 20(2), 236-260. doi:10.1080/10864415.2016.1087823

Lindgaard, G., Fernandes, G., Dudek, C. ve Brown, J. (2006). Attention web designers: You have 50 milliseconds to make a good first impression! Behaviour \& Information Technology, 25(2), 115-126. doi:10.1080/01449290500330448

Lovelock, C. ve Wirtz, J. (2011). Services Marketing: People Technology, Strategy (7. bs.). New Jersey: Pearson Prentice Hall.

Marberry, S. O. ve Zagon, L. (1995). Power of Color - Creating Healthy Interior Spaces. New York, USA: John Wiley \& Sons.

Massara, F., Liu, S. S. ve Melara, R. D. (2010). Adapting to a retail environment: Modeling consumer-environment interactions. Journal of Business Research, 63(7), 673-681. doi:10.1016/j.jbusres.2009.05.004

McDougall, S. J., Curry, M. B. ve de Bruijn, O. (1999). Measuring symbol and icon characteristics: norms for concreteness, complexity, meaningfulness, familiarity, and semantic distance for 239 symbols. Behavior research methods, instruments, \& computers : a journal of the Psychonomic Society, Inc, 31(3), 487-519. doi:10.3758/BF03200730

Mehrabian, A. ve Russell, J. A. (1974). An Approach to Environmental Psychology. Cambridge, MA: The MIT Press.

Menon, S. ve Kahn, B. (2002). Cross-category effects of induced arousal and pleasure on the internet shopping experience. Journal of Retailing, 78(1), 31-40. doi:10.1016/S0022-4359(01)00064-1

Moshagen, M. ve Thielsch, M. T. (2010). Facets of visual aesthetics. International Journal of Human Computer Studies, 68(10), 689-709. doi:10.1016/j.ijhcs.2010.05.006

Nasar, J. L. (2000). The Evaluative Image of Places. W. B. Walsh, K. H. Craik ve R. H. Price (Ed.), Person-Environment Psychology içinde (ss. 117-168). Mahwah, NJ: Lawrence Erlbaum Associates.

Ng, A. W. Y. ve Chan, A. H. S. (2008). Visual and Cognitive Features on Icon Effectiveness. Computer, II, 19-21.

Norman, D. A. (2004). Emotional Design. New York, USA: Basic Book.

Nunnally, J. C. (1978). Psychometric theory. McGraw-Hill series in psychology (2nd bs.). New York: McGraw-Hill, c1978.

Papachristos, E., Tselios, N. ve Avouris, N. (2005). Inferring Relations Between Color and Emotional Dimensions of a Web Site Using Bayesian Networks. Lecture Notes in Computer Science içinde (C. 3585 LNCS, ss. 1075-1078). doi:10.1007/11555261 108

Pol, M. (2015). App icon preferences : The influence of app icon design and involvement on quality and intention to download. University of Twente.

Reinecke, K., Yeh, T., Miratrix, L., Mardiko, R., Zhao, Y., Liu, J. ve Gajos, K. Z. (2013). Predicting users' first impressions of website aesthetics with a quantification of perceived visual complexity and colorfulness. Proceedings of the SIGCHI Conference on Human Factors in Computing Systems - CHI '13 içinde (s. 2049). New York, USA: ACM Press. doi:10.1145/2470654.2481281

Russell, J. A. ve Snodgrass, J. (1987). Emotion and the Environment. D. Stokols ve I. Altman (Ed.), Handbook of Environmental Psychology içinde (1. bs., ss. 245-281). New York: John Wiley \& Sons. 
Sherman, E., Mathur, A. ve Smith, R. B. (1997). Store environment and consumer purchase behavior: Mediating role of consumer emotions. Psychology and Marketing, 14(4), 361-378. doi:10.1002/(SICI)1520-6793(199707)14:4<361::AID-MAR4>3.0.CO;2-7

Shu, W. ve Lin, C.-S. (2014). Icon Design and Game App Adoption. 20th Americas Conference on Information Systems içinde (ss. 1-14). Savannah.

Singh, S. (2006). Impact of color on marketing. Management Decision, 44(6), 783-789. doi:10.1108/00251740610673332

Skorinko, J. L., Kemmer, S., Hebl, M. R. ve Lane, D. M. (2006). A rose by any other name ...: Color-naming influences on decision making. Psychology and Marketing, 23(12), 975-993. doi:10.1002/mar.20142

Spalter, A. M. (1999). The Computer in Visual Arts. Reading: Addison-Wesley.

Stone, M. (1974). Cross-validatory choice and assessment of statistical predictions. Journal of the Royal Statistical Society, 36, $111-147$.

Taba, S. E. S., Keivanloo, I., Zou, Y., Ng, J. ve Ng, T. (2014). Web Engineering: 14th International Conference, ICWE 2014, Toulouse, France, July 1-4, 2014. Proceedings. S. Casteleyn, G. Rossi ve M. Winckler (Ed.), (ss. 370-379). Cham: Springer International Publishing. doi:10.1007/978-3-319-08245-5_22

Technavio. (2015). Global Mobile Application Market 2015-2019. 17 Eylül 2015 tarihinde http://www.technavio.com/report/global-mobileapplication-market-2015-2019 adresinden erişildi.

Thüring, M. ve Mahlke, S. (2007). Usability, aesthetics and emotions in human-technology interaction. International Journal of Psychology, 42(4), 253-264. doi:10.1080/00207590701396674

Tuch, A. N., Bargas-Avila, J. a. ve Opwis, K. (2010). Symmetry and aesthetics in website design: It's a man's business. Computers in Human Behavior, 26(6), 1831-1837. doi:10.1016/j.chb.2010.07.016

Tunali, I. (2011). Estetik (13. bs.). Istanbul: Remzi Kitabevi.

Veryzer, J. R. W. (1995). The place of product design and aesthetics in consumer research. Advances in consumer research, 22(1), 783-785.

Wooldridge, D. ve Schneider, M. (2010). The Business of iPhone and iPad App Development Making and Marketing Apps That Succeed. Intellectual Property. doi:10.1007/978-1-4302-3301-5

Wu, O., Chen, Y., Li, B. ve Hu, W. (2011). Evaluating the visual quality of web pages using a computational aesthetic approach. Proceedings of the fourth ACM international conference on Web search and data mining - WSDM '11 içinde (s. 337). New York, USA: ACM Press. doi:10.1145/1935826.1935883

Zeithmal, V. (1988). Consumer perceptions of price, quality and value: a means-end model and synthesis of evidence. Journal of Marketing, $52(3), 2-22$. 


\section{EK-1: Uygulama İkonları}

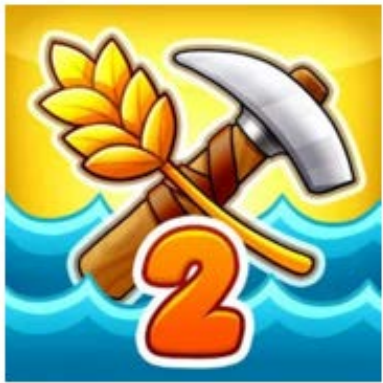

01

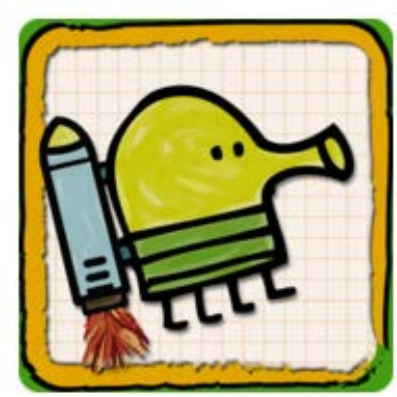

$\mathrm{O} 3$

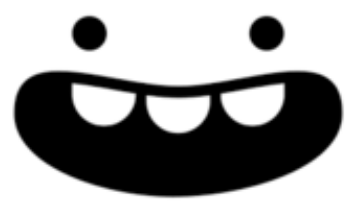

O5

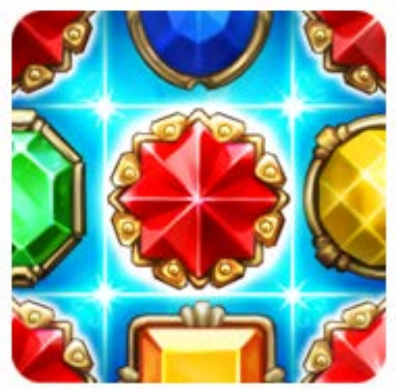

$\mathrm{O} 2$

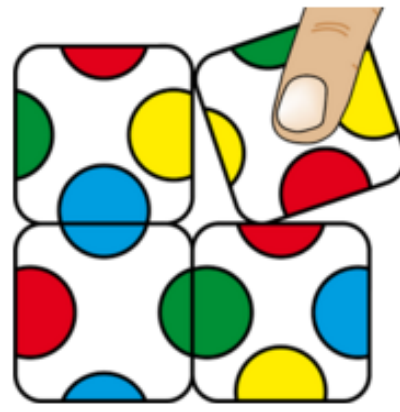

04

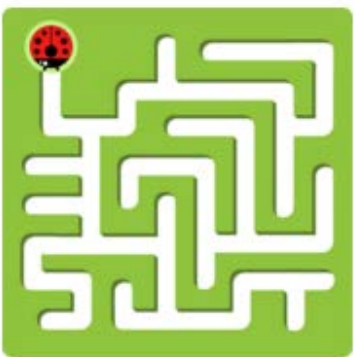

06 
EK-2: Değişkenler geçerlilik ve güvenirlik analizleri, ve çapraz yüklemeler

\begin{tabular}{|c|c|c|c|c|c|c|c|c|c|c|c|c|c|}
\hline $\begin{array}{l}\text { Örtük } \\
\text { Değişken }\end{array}$ & $\begin{array}{l}\text { Ort. } \\
\text { Çıkartılan } \\
\text { Varyans } \\
\text { (AVE) }\end{array}$ & $\begin{array}{l}\text { Bileşik } \\
\text { Güvenilirlik } \\
\text { Katsayısı } \\
\text { (CR) }\end{array}$ & $\begin{array}{l}\text { Cronbach } \\
\text { Alfa (CA) }\end{array}$ & UYA & BST & $\mathrm{KAL}$ & ANL & NiY & HOŞ & RNK & sim & SOM & AŞN \\
\hline UYA & .8366 & .9388 & .9027 & .9146 & & & & & & & & & \\
\hline BST & 1 & 1 & 1 & .1735 & 1 & & & & & & & & \\
\hline $\mathrm{KAL}$ & .8152 & .9295 & .8856 & .4998 & .0385 & .9029 & & & & & & & \\
\hline NiY & .9245 & .9735 & .9591 & .4096 & .0743 & .6908 & .2150 & .9615 & & & & & \\
\hline HOŞ & .8483 & .9437 & .9105 & .6027 & .1544 & .4606 & .2482 & .4325 & .9210 & & & & \\
\hline RNK & 1 & 1 & 1 & .2636 & .0529 & .2325 & .2672 & .1376 & .1361 & 1 & & & \\
\hline sim & 1 & 1 & 1 & .3351 & .1702 & .3238 & .2418 & .1959 & .2941 & .2691 & 1 & & \\
\hline
\end{tabular}

* Ortalama açıklanan varyansın karekökü diyagonal üzerinde belirtilmiştir. UYA: Uyarılma, BST: Basitlik, KAL: Kalite, ANL: Anlamlıık, NiY: Niyet, HOŞ: Hoşa Gitme, RNK: Renklilik, SiM: Simetrik, SOM: Somutluk, AŞN: Aşinalık 